East African Medical Journal Vol. 86 (Supplement) January 2009

MONITORING AND EVALUATION OF HEALTH SECTOR REFORMS IN THE WHO AFRICAN REGION

S. P. Barry, MD, MPH, Programme Manager, Health Policies and Service Delivery, A.J. Diarra-Nama, PhD., Director, Health Systems and Services Development, J. M. Kirigia,PhD, Programme Manager, Health Financing and Social Protection, WHO Regional Office for Africa, BP 06, Brazzaville, Congo, S. Bakeera, MD, Masters in Health Management, Planning and Policy, Freelance Consultant, P.O. Box 2762, Kampala, Uganda and H. Somanje, MBBS, MPH, Medical Officer, Health Policies and Services Delivery Programme, WHO Regional Office for Africa, BP 06, Brazzaville, Congo

Request for reprints to: Dr. S. P. Barry, Health Policies and Services Delivery Programme, Division of Health Systems and Services Development, WHO Regional Office for Africa, BP 06, Brazzaville, Congo

\title{
MONITORING AND EVALUATION OF HEALTH SECTOR REFORMS IN THE WHO AFRICAN REGION
}

\author{
S. P. BARRY, A.J. DIARRA-NAMA, J. M. KIRIGIA, S. BAKEERA and H. SOMANJE
}

\begin{abstract}
Objectives: To describe a comprehensive analytical framework for assessing health sector reforms and demonstrates use of the analysis framework using cost-recovery mechanisms as a case study in the WHO African Region.

Data sources: Health sector reforms published literature review.

Study selection: No selection involved.

Data extraction: This paper draws from previous published literature to describe a comprehensive framework to assess the performance of health sector reforms in the African region. Using this framework, it goes on to illustrate how it may be used to analyze cost recovery reforms as a case study. The major elements for the analysis include a description of the context, design, process and intended results.

Data synthesis: In terms of context and design of the cost recovery reform, there were gaps in the stewardship role of governments as evidenced by the lack of appropriate policies and information to monitor and/or influence the process. Regarding the cost recovery implementation, it is not clear from the literature reviewed in this paper that there was a comprehensive stakeholder coordination mechanism that catered for all who were involved. Concerning results of the expected results of implementing cost recovery reforms such as improved quality of health services; equitable service utilisation; social sustainability through active community participation; and gains in efficiency were not always realised.

Conclusions: Given that the aspects of the analysis framework described in this paper are interrelated, reviewing one without another provides an answer to a specific question but is insufficient for a comprehensive assessment.
\end{abstract}

\section{INTRODUCTION}

Over the last two decades, most African countries have implemented various health sector reforms to address gaps in access, equity, quality, effectiveness, efficiency and sustainability of health systems(1). Concurrently, several other global initiatives (such as the Millennium Development Goals; Declaration of the World Summit on Children; Health for All in the 21st Century; and New Partnership for the African Development) that promise an increased leverage for improvements in population health were adopted.

Health sector reforms (HSR) can be described as sustained, purposeful and fundamental changes intended to improve the performance of the sector in terms of efficiency, equity and effectiveness (2). Implementation of HSR in the region has not always been in response to identified gaps within the sector. Some health sector reforms have been imposed as part of broader economic reform 
policy. The main reforms in the past two decades have included decentralisation of health services management and operation to sub-national levels; health financing initiatives such as user fees in the public sector, community co-management and cofinancing mechanisms centred on essential drugs (Bamako initiative); organization of health services including autonomy of management to hospitals and promotion of public/private partnerships. More recently, some countries have considered the introduction of social health insurance $(1,3)$.

Monitoring and evaluation of health sector reforms are critical for identifying whether they have met or are likely to meet their primary aims. They also provide feed-back to countries and development partners so that changes can be made if strategies do not appear to be working or simply need fine-tuning (4).There have been various efforts to assess the impact of implementing HSR in the region (1-5), each of these lay emphasis on some and not all aspects needed to provide a comprehensive analysis. This paper therefore draws from previous published literature to describe a comprehensive framework to assess the performance of reforms in the African region. Using this framework, it goes on to illustrate how it may be used to analyze cost recovery reforms as a case study.

\section{MATERIALS AND METHODS}

Conceptual framework: The major elements for analysis of a health sector reform include a description of the context, design, process and intended results (1). Figure 1 lays out a conceptual framework for this analysis.

Context for health sector reform: Health sector reform does not take place in a vacuum and therefore analysis of the context should provide clear and detailed descriptions of the key factors driving the reform. The context of the reform will be closely related to why it was placed on the agenda. The context will therefore be related to whether it is in response to an external factor such as broader macroeconomic reforms or purposefully created to address an issue within the health sector such as the need to scale up access to new technologies/medicines. The analysis in this case identifies the impetus for the reform.

Health sector reform design: The design of a health sector reform takes into consideration what mechanisms will be manipulated to effect the desired change; which key stakeholders will be involved at the various stages; and their various interests, mandates and the potential to (re) - direct

Figure 1

Health sector reforms context, design, implementation and results

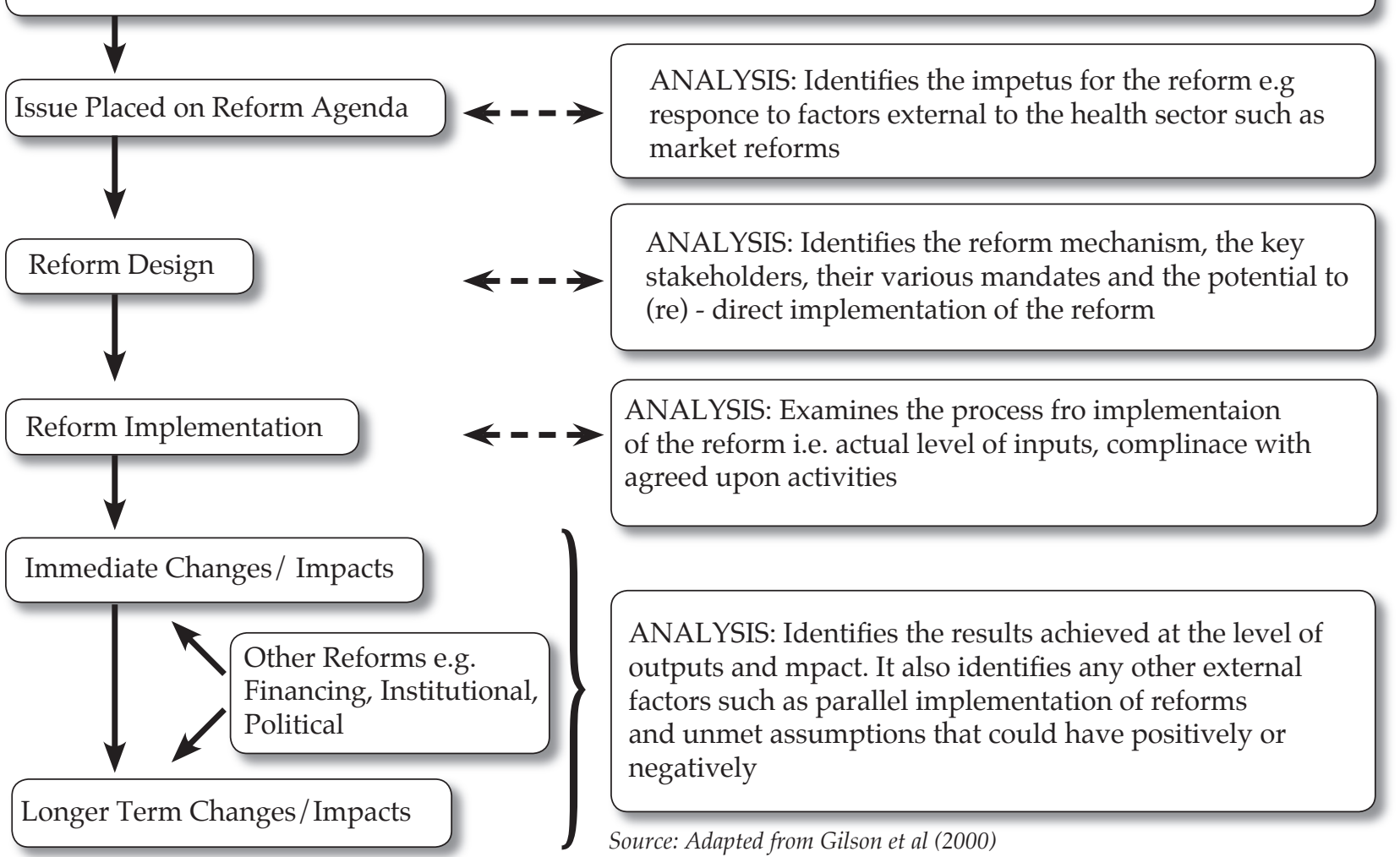


Table 1

Evaluative questions for the dynamics of a reform

\begin{tabular}{|c|c|c|c|}
\hline Aspect assessed & Evaluative question & Rationale & Data source \\
\hline Context & $\begin{array}{l}\text { What is the genesis of the } \\
\text { reform? }\end{array}$ & $\begin{array}{l}\text { - Identifies the impetus and therefore } \\
\text { the wider political, socioeconomic } \\
\text { and policy environment }\end{array}$ & $\begin{array}{l}\text { Key } \\
\text { informant } \\
\text { interviews } \\
\text { Policy } \\
\text { documents }\end{array}$ \\
\hline & $\begin{array}{l}\text { What is the political and } \\
\text { wider policy environment? } \\
\text { What is the chronology of } \\
\text { strategic events leading } \\
\text { up to adoption of the } \\
\text { reform e.g. formulation of } \\
\text { supporting policies? }\end{array}$ & $\begin{array}{l}\text { - To identify the wider reform } \\
\text { environment that may influence } \\
\text { implementation of the reform e.g. } \\
\text { sources of conflict, bureaucracy } \\
\text { - Explains the extent to which } \\
\text { any improvements or decline in } \\
\text { performance can be attributed to } \\
\text { implementation of the reform } \\
\text { - Forms basis for key assumptions } \\
\text { for reform progress }\end{array}$ & $\begin{array}{l}\text { Key } \\
\text { informant } \\
\text { interviews } \\
\text { Policy } \\
\text { documents }\end{array}$ \\
\hline \multirow[t]{2}{*}{ Design } & $\begin{array}{l}\text { Who are the main actors } \\
\text { and what are their } \\
\text { mandates? }\end{array}$ & $\begin{array}{l}\text { - Identifies the key stakeholders, } \\
\text { their various mandates and } \\
\text { the potential to (re)-direct } \\
\text { implementation of the reform. }\end{array}$ & $\begin{array}{l}\text { Key } \\
\text { informant } \\
\text { interviews }\end{array}$ \\
\hline & $\begin{array}{l}\text { What is the design of the } \\
\text { reform? }\end{array}$ & $\begin{array}{l}\text { - Determines its viability, relevance } \\
\text { of the mechanism in addressing the } \\
\text { identified problem } \\
\text { - Enables the mapping of potential } \\
\text { conflicts, capacity gaps }\end{array}$ & $\begin{array}{l}\text { Key } \\
\text { informant } \\
\text { interviews } \\
\text { Policy } \\
\text { documents }\end{array}$ \\
\hline
\end{tabular}

implementation of the reform. It also considers whether the reform is appropriate to address the identified health issues. Analysis of this level needs a careful review of each of these areas and how they were executed. The evaluative questions that may be asked for the context and design of a reform are included in Table 1.

Health sector reform implementation: Analysis of the implementation stage reviews the actual level of inputs and compliance with agreed upon activities. Inputs to be reviewed will include finances, human resource time and skills, and other logistics. The activities to be reviewed relate to the organization of inputs in relation to implementation of the reform. Inputs will not always be quantitative and could relate to a process that requires a qualitative assessment. Table 2 includes the evaluative questions related to the assessment of a health sector reform.

Health sector reform results: A review of the results achieved is carried out at the level of outputs, outcomes and impact. The review should also identify external factors such as parallel implementation of reforms and unmet assumptions that could have positively or negatively influenced reform implementation. Reviewing the results will also enable one to determine if the health sector objectives have been met. Table 3 proposes indicators for assessing inputs required to operationalise cost 


\section{Table 2}

Evaluative questions for the process of a reform

\begin{tabular}{|c|c|c|c|}
\hline Aspect assessed & Evaluative questions & Rationale & Data source \\
\hline $\begin{array}{l}\text { Stakeholder } \\
\text { participation and } \\
\text { participation } \\
\text { mechanisms }\end{array}$ & $\begin{array}{l}\text { - What are the stakeholder } \\
\text { coordination mechanisms at } \\
\text { district level? } \\
\text { - Do community/public } \\
\text { participation mechanisms } \\
\text { exist? } \\
\text { - How functional are the } \\
\text { stakeholder participation/ } \\
\text { coordination mechanisms at } \\
\text { sub-national level? } \\
\text { - Are all key stakeholders } \\
\text { meeting their obligations and } \\
\text { commitments? }\end{array}$ & $\begin{array}{l}\text { - Provides facilitation for } \\
\text { stakeholders to review } \\
\text { and re-direct progress } \\
\text { as required, as well as } \\
\text { achieving consensus and } \\
\text { conflict resolution among the } \\
\text { different stakeholders } \\
\text { - Public participation is } \\
\text { anticipated to have a positive } \\
\text { effect on equity, quality and } \\
\text { efficiency of service delivery } \\
\text { outputs } \\
\text { - Social participation } \\
\text { facilitates acceptance of } \\
\text { a reform, enabling its } \\
\text { sustainability at this level }\end{array}$ & $\begin{array}{l}\text { Key informant } \\
\text { interviews }\end{array}$ \\
\hline \multirow[t]{2}{*}{ Timing } & $\begin{array}{l}\text { - Are inputs being delivered } \\
\text { in a timely manner in } \\
\text { relation of to the timed } \\
\text { progress of the reform? } \\
\text { - How timely are inputs and } \\
\text { stakeholder participation? }\end{array}$ & $\begin{array}{l}\text { - This determines the } \\
\text { progress of implementation } \\
\text { - Determines the } \\
\text { achievement of key } \\
\text { milestones in reform } \\
\text { implementation }\end{array}$ & $\begin{array}{l}\text { Health } \\
\text { information } \\
\text { systems } \\
\text { Key informant } \\
\text { interviews }\end{array}$ \\
\hline & & & Review reports \\
\hline
\end{tabular}

recovery mechanisms. Table 4 presents indicators for assessing the impact of the cost recovery reforms.

\section{RESULTS}

Monitoring and evaluation of health financing reforms: a case study for cost recovery mechanisms: The assessment of cost recovery reforms uses information from published papers on both user fees and the Bamako initiative. The limitation of this data source is that it does not include all aspects of the described analysis framework. More appropriate data sources for a comprehensive assessment are provided in Tables 1-4.

The context and design for cost recovery reforms: The impetus for cost recovery reforms was on the one hand in response to broader health financing reforms. On the other hand, it was also promoted as a means to address chronic shortages of essential supplies in the health sector. Thus the deteriorating public health care and the pressure to comply with broader macro-economic reforms created a conducive environment for the adoption of cost recovery mechanisms. Multilateral agencies were major stakeholders in the launching and promotion of the Bamako initiative. Both WHO and UNICEF promoted the initiative as a strategy to reduce infant and child mortality mainly through improving and ensuring the availability of essential medicines and supplies (6-8). The agenda of the World Bank was mainly economic, believing that such a measure would obviate the need for poor governments to finance all health care as well as improving efficiency. In the adoption of the initiative in 1988, it is apparent that the governments of these poor countries bought into the multilateral agencies' agenda. A 
Table 3

Indicators for inputs of a reform

\begin{tabular}{|c|c|c|c|}
\hline Indicator variable & Indicator1 & Rationale & Data source \\
\hline $\begin{array}{l}\text { Human resource } \\
\text { numbers and } \\
\text { skills }\end{array}$ & $\begin{array}{l}\text { - Number of positions filled } \\
\text { in accordance with staffing } \\
\text { norms for appropriate } \\
\text { financial management } \\
\text { - Proportion trained to meet } \\
\text { new management and service } \\
\text { requirements }\end{array}$ & $\begin{array}{l}\text { - Implementation } \\
\text { and management of a } \\
\text { cost recovery financial } \\
\text { management skills. } \\
\text { - The cost recovery scheme } \\
\text { also creates need for financial } \\
\text { management training } \\
\text { - Number and skills of } \\
\text { health workers will influence } \\
\text { the capacity for effective } \\
\text { implementation }\end{array}$ & $\begin{array}{l}\text { - Human } \\
\text { resource } \\
\text { inventory } \\
\text { - Training } \\
\text { reports }\end{array}$ \\
\hline Finances & $\begin{array}{l}\text { - Net contribution of cost } \\
\text { recovery schemes to total } \\
\text { budget }\end{array}$ & $\begin{array}{l}\text { - Demonstrates capacity of } \\
\text { the cost recovery scheme to } \\
\text { increase financial resources }\end{array}$ & $\begin{array}{l}\text { - Income and } \\
\text { expenditure } \\
\text { records } \\
\text { - Budgets and } \\
\text { work-plans }\end{array}$ \\
\hline $\begin{array}{l}\text { Medicines, } \\
\text { supplies, and } \\
\text { equipment; } \\
\text { operations and } \\
\text { maintenance }\end{array}$ & $\begin{array}{l}\text { - Net contribution of cost } \\
\text { recovery schemes to purchase } \\
\text { of medicines, supplies, } \\
\text { operations and maintenance }\end{array}$ & $\begin{array}{l}\text { - Demonstrates district } \\
\text { capacity to address and/or } \\
\text { improve logistic gaps }\end{array}$ & $\begin{array}{l}\text { Medicine and } \\
\text { supply stock } \\
\text { cards; } \\
\text { Equipment } \\
\text { inventories; } \\
\text { Review reports }\end{array}$ \\
\hline $\begin{array}{l}\text { Infrastructure and } \\
\text { equipment }\end{array}$ & $\begin{array}{l}\text { - Proportion of infrastructure } \\
\text { and equipment budget that } \\
\text { is funded using finances from } \\
\text { cost recovery schemes }\end{array}$ & $\begin{array}{l}\text { - Demonstrates capacity to } \\
\text { finance large capital items }\end{array}$ & $\begin{array}{l}\text { - Income and } \\
\text { expenditure } \\
\text { records } \\
\text { - Budgets and } \\
\text { work-plans }\end{array}$ \\
\hline
\end{tabular}

Note; 1 The denominator for each of these indicators will depend of the factor being assessed e.g. Number of positions filled in accordance with staffing norms: in this case the denominator will be either the total positions available for all cadres or the total for a selected cadre; the numerator in this case will be the actual positions filled.

later endorsement by African health ministers and other senior officials additionally recognised quality improvement in service provision as a rationale for charging patients. In spite of commitment at such a high level, there were gaps in the stewardship role of governments as evidenced by the lack of appropriate policies and information to monitor and / or influence the process $(6,9)$.

Given that communities were already paying for health care use, resistance towards cost recovery initiatives was not anticipated $(6,9)$. This assumption probably did not take into consideration the $5-30 \%$ 


\section{Table 4}

Indicators for the outcomes and impact of a reform

\begin{tabular}{|c|c|c|c|}
\hline Aspect assessed & Indicator & Rationale & Data source \\
\hline Equity & $\begin{array}{l}\text { - Access - Not relevant } \\
\text { - Coverage Proportion of } \\
\text { the poor utilising public } \\
\text { health services where user } \\
\text { fees have been instituted } \\
\text { Distribution of resources } \\
\text { - financial, human resources } \\
\text { by geographical area/per } \\
\text { capita } \\
\text { - Resource utilisation - Out } \\
\text { Patient Department per } \\
\text { capita/for socio-economic } \\
\text { status } \\
\text { - Impact on health status } \\
\text { indicators - reduction } \\
\text { in IMR/U5MR/MR by } \\
\text { socio-economic status or } \\
\text { geographical region }\end{array}$ & $\begin{array}{l}\text { To establish the effect of the } \\
\text { reform on the geographical } \\
\text { or socio-economic disparities } \\
\text { in: } \\
\text { i) Access } \\
\text { ii) coverage } \\
\text { iii) ability to pay full cost of } \\
\text { using services } \\
\text { iv) distribution of resources } \\
\text { v) resource utilisation } \\
\text { disparities for access to care } \\
\text { amongst vulnerable groups } \\
\text { vi) health status indicators } \\
\text { e.g. infant mortality rate, } \\
\text { maternal mortality ratio }\end{array}$ & $\begin{array}{l}\text { - Health facility } \\
\text { inventories } \\
\text { - Routine HMIS } \\
\text { - Household } \\
\text { surveys } \\
\text { - Demographic } \\
\text { health surveys } \\
\text { - Special studies }\end{array}$ \\
\hline Quality & $\begin{array}{l}\text { Technical quality - } \% \text { of } \\
\text { facilities with quality control } \\
\text { mechanisms; availability } \\
\text { of essential medicines and } \\
\text { commodities; } \\
\text { Perceived quality - degree } \\
\text { of user satisfaction with the } \\
\text { health services }\end{array}$ & $\begin{array}{l}\text { To assess effect of quality } \\
\text { on other variables such as } \\
\text { equity and efficiency }\end{array}$ & $\begin{array}{l}\text { - Supervision } \\
\text { reports } \\
\text { - Survey reports } \\
\text { - Special studies }\end{array}$ \\
\hline Efficiency & $\begin{array}{l}\text { Resource allocation - trends } \\
\text { for service delivery inputs } \\
\text { per given output }\end{array}$ & $\begin{array}{l}\text { - Assesses whether more } \\
\text { efficient resource allocation } \\
\text { mechanisms have been } \\
\text { introduced e.g. evidence for } \\
\text { resource allocation to higher } \\
\text { burden health conditions }\end{array}$ & $\begin{array}{l}\text { Income and } \\
\text { expenditure } \\
\text { records at } \\
\text { national and sub- } \\
\text { national levels }\end{array}$ \\
\hline Sustainability & $\begin{array}{l}\text { - Availability of the required } \\
\text { resources to meet medium } \\
\text { term targets for e.g. scaling } \\
\text { up access }\end{array}$ & $\begin{array}{l}\text { - Will determine the viability } \\
\text { of the reform in the short and } \\
\text { medium term }\end{array}$ & $\begin{array}{l}\text { - Key informant } \\
\text { interviews } \\
\text { - Medium and } \\
\text { Long Term } \\
\text { Expenditure } \\
\text { Framework }\end{array}$ \\
\hline
\end{tabular}


of the sub-Saharan population that is unable to afford payment for health care (7). It is therefore not surprising that objection by the poor to cost recovery led to abolition of user fees in 2003 in the Uganda public sector (10).

The focus of the cost recovery mechanisms on patient as opposed to provider behaviour (11) could have contributed to the flaunting of the rules through the emergence of under the table fees to compensate health workers who were losing out in the implementation of the initiative (9). The higher price structure for some services led intended beneficiaries to opt for private health services, making the latter important stakeholders (12).

Health sector reform implementation: It is not clear from the literature reviewed in this paper that there was a comprehensive stakeholder coordination mechanism that catered for all who were involved. There was though a public participation mechanism through health committees. Communities as the intended direct beneficiaries had management structures that potentially created avenues for an oversight function in terms of implementation of the initiative. For instance, health committees representing communities were said to be able to hold monitoring sessions in which coverage targets, inputs and expenditures were set, reviewed and analysed and compared (8). These committee members in some cases as in Niger had conflicting interests in the management of the scheme and no clear mandates and legal positions. Also in reality, the district health teams often filled in for community members, in essence creating a lack of ownership of the scheme at this level (12). So one might say that the public participation mechanism were not fully functional. This also means that the opportunity to support social sustainability of the reform was not fully exploited.

At the implementation level, the inputs in terms of financial and human resources needed to support cost recovery schemes were largely underestimated. Additionally, although there was often clear consensus on the process and level of activities, this was not always complied with especially at the operational level. Some assumptions on key processes were made that were either insufficient or not implemented. For instance it was assumed that coordinating prices across levels of care would strengthen appropriate referral. This was insufficient to improve the referral network as clients continued to bypass lower level facilities. It was also assumed that exemption from payment would encourage use of services such as antenatal care and treatment for tuberculosis; there was little evidence to suggest that this had happened. For the assumption that providers would be encouraged to improve quality of care as well as limiting over-prescription, the reverse actually occurred (6).

There are several examples that point to the shortfalls of human resource inputs. The decline in support supervision of the cost recovery scheme was related to the lack of capacity and insufficient motivation and in Niger contributed to financial mismanagement (12). In Burkina Faso, there was lack of accountability resulting from poor financial record maintenance showing profit and loss for the essential medicines depots (7).

Other input shortfalls were for medicines and supplies. Meuwissen (12) notes that in even apparently well-designed schemes such as the one in Niger, stock outs of essential medicines with the permitted wholesalers implied an absence of supplies at the operational level.

\section{DISCUSSION}

The results that were expected included: an increase in cost recovery that would then be channeled to improve the quality of services; equitable service utilisation in favour of the poor; social sustainability through active community participation $(7,12)$; gains in efficiency would be partly through the reduction in unnecessary use of services (13).

There was failure to attain these results due to partly weaknesses at the design stage. Although the multilateral agencies had a noble and clear agenda and governments committed at the highest level, their mandates fell short of influencing correct implementation at the district and community level.

Involvement of external partners in pilot studies yielded expected results but this was not replicated globally in the absence of such support. For instance in Cameroon and Niger where specialised technical assistance and considerable external funding was provided, it was possible to demonstrate a positive impact on service utilisation in favour of the poor who were the intended beneficiaries. In both settings, quality of care and appropriate targeting of the poor were met (14). 
In other countries including Ghana, Kenya, Lesotho, Uganda, Zambia and Niger, the introduction of user fees actually contributed to reduction in service utilisation $(12,13,15)$ and minimally to cost recovery $(6,16)$. A similar finding is reported in Nigeria where the introduction of the Bamako initiative actually favoured the least poor $(6,9)$.

In Swaziland, up to one third of drop in attendance attributed to the poorest (17). In Lesotho the decrease in utilisation occurred mostly in remote areas with difficult terrain and also for children less than five years who are the most vulnerable (6). The way in which it was implemented in some cases contributed to inequity e.g. in Kenya where it was permitted to collect, retain and use fees at point of collection, provinces with hospitals able to collect more than those without, owing to the absence of a mechanism to redistribute resources from better off areas (6).

\section{CONCLUSION}

The published papers reviewed in this report answer some but not all the questions described in the analysis framework. A comprehensive analysis is not always required or feasible for assessing a reform. However the aspects described in this paper are interrelated and whilst reviewing one without another provides an answer to a specific question it is insufficient for a comprehensive assessment.

\section{COMPETING INTERESTS}

The authors declare that they have no competing interest.

\section{AUTHORS CONTRIBUTIONS}

All the authors were involved in the conception, design, analysis and drafting of the manuscript.

\section{REFERENCES}

1. Gilson L. and Mills A. Health Sector Reforms in subSaharan Africa: lessons of the last ten years. Health Policy. 1995; 32: 215 - 243.

2. Berman A. and Bossert T.J. A decade of Health Sector Reform in Developing Countries: What have we learned? Washington D.C.: World Bank; 2000.

3. Hutchinson P.L. and Lafond A.K. Monitoring and evaluation of decentralization deforms in developing country health sectors. Boston: Partners for Health Reformplus; 2004.

4. O'Neill P.D. and Nath U.R. Make it happen: how decision-makers can use policy and research to strengthen health systems. Geneva:Global Forum for Health Research; 2005.

5. Kolehmainen-Aitken R.L. Decentralization's impact on the health workforce: Perspectives of managers, workers and national leaders. Human Resources for Health 2004, 2:5. http://www.human-resources-health. com/content $/ 2 / 1 / 5$

6. Creese A. and Kutzin J. Lessons from cost-recovery in health. Forum on health sector reform, Discussion paper 2. Geneva: WHO; 1995.

7. Ridde V. Fees-for-services, cost recovery, and equity in a district of Burkina Faso. Bull. World Health Org. 2003; 81 : 532-538.

8. Paganini A. The Bamako Initiative was not about money. Health Policy Dev. 2004; 2: 11-13

9. Brunet-Jailly J. Health financing in the poor countries: Cost recovery of cost reduction. Population Health, and Nutrition Working Papers WPS 692. Washington D.C. World Bank; 1991.

10. Nabyonga J., Desmet M., Karamagi H., Kadama P.Y., Omaswa F.G. and Walker O. Abolition of cost-sharing is pro-poor: evidence from Uganda. Health Policy Plan 2005; 20: 100-108.

11. Uzochukwu B.S.C., Onwujekwe O.E. and Erikson B. Inequity in Bamako initiative: Implications for malaria control in southeast Nigeria. Inter J Health Plann Man. 2004; 19 (Supp 1) 1:S107-S116.

12. Meuwissen L.E. Problems of cost recovery implementation in district health care: a case study from Niger. Health Policy Plann. 2002; 17:304-313.

13. Creese A. and Kutzin J. Lessons from cost recovery in health.. In: Marketing education and health in developing countries, miracle or mirage? Edited by Colclough C. Oxford: Clarendon Press; 1997:37-62.

14. Litvack J.I. and Bodart C. User fees plus quality equals improved access to health care: results of a field experiment in Cameroon. Social Sci. Med. 1993; 37:369-683.

15. Waddington C. and Enyimayew K. A price to pay. Part 2 : The impact of user fees in Volta Region of Ghana. Int. J. Health Plann. Man. 1990; 5: 287-312.

16. Okuonzi S.A. Learning from failed health reform in Uganda. BMJ 2004; 329:1173-1175.

17. Yoder R.A. Are people willing and able to pay for health services? Social Sci. Med. 1989; 29:35-42. 